\title{
Adopting a global perspective in the discipline consumer science
}

\author{
Alet C Erasmus, Martha Kok \& Arda Retief
}

\begin{abstract}
Opsomming
' $n$ Oorwegend materialistiese waardestelsel en blootstelling aan die kragte van 'n ekonomiese markstelsel, het meegebring dat die moderne verbruiker ' $n$ groot premie plaas op besittings en daarop ingestel is om weelde-artikels te versamel. Met persoonlike bevrediging as dryfveer en die strewe om hulle lewenstyl te verbeter, gaan verbruikers dikwels tot uiterstes om behoeftes aan goedere en dienste te laat realiseer.
\end{abstract}

As in aanmerking geneem word dat die aarde se hulpbronne beperk is en dat die huidige wêreldpopulasie reeds meer gebruik as wat vervang kan word, is dit belangrik dat dit ons erns word om ons bestedingspraktyke te heroorweeg en om aanpassings te maak. 'n Wêreldperspektief in verbruikersgedrag word as alternatief voorgehou, dit wil sê doelbewuste aksies om ' $n$ volhoubare verbruikpatroon aan te moedig wat tot 'n eenvoudiger lewenstyl sal lei en wat sal verseker dat ons verbruik nie ten koste van die minder gegoede en ook toekomstige generasies is nie.

Die basiese beginsels wat die aannames van 'n wêreldperspektief tot verbruikersgedrag saamvat, word genoem en kortliks bespreek. Daar word voorts beklemtoon dat enige beroep op die mensdom as verbruikers van hulpbronne, om te verander en om aanpassings te maak, prakties en uitvoerbaar moet wees om uiteindelik ' $n$ lewensbenadering te kan word.

\section{- Mrs AC Erasmus \\ - Mrs M Kok \\ - Mrs A Retief \\ Department of Consumer Science University of Pretoria}

\section{CONSUMER SATISFACTION: THE NORM}

Consumer behaviour of the western world can generally be described as materialistic, mainly selfish orientated and dominated by commercially centered motives that encourage the accumulation of wealth and possessions (Du Plessis \& Rousseau, 1999:332). Accumulating possessions rather than being satisfied with a simple uncluttered lifestyle (Schiffman \& Kanuk, $2000: 106$ ), consumers are often willing to go to extremes to fulfil specific product requirements and to achieve consumer satisfaction. Continuously on the look out for new products and new pleasures and even replacing products before they are worn out, western world consumers have in fact instigated a situation where production figures can be expected to expand forever (Shove \& Warde, 1998; Ger \& Belk, 1996; Cooper, 1994). Driven by economic principles, the retail environment encourages and even promotes a materialistic value system. Although many consumers will deny being materialistic, every day consumer related behaviour in the Western world unfortunately bears testimony of the opposite!

Deacon and Firebaugh (1985:31) summarize man's approach from an economical perspective as follows: We have tried to control and modify our environment, including climate, probably more than ourselves. Our emphasis seems to be on modifying the environment rather than on modifying or controlling the human organism to give it the innate capability to cope with the environment.

\section{INTRODUCING A GLOBAL PERSPECTIVE IN CONSUMER BEHAVIOUR}

No wonder then that a growing outcry has emerged to promote a global perspective ${ }^{1}$ in consumer science. A global perspective in essence refers to a social process of intensifying the relations between the different parts of the world (an ecological systems approach) in

1 Globalization refers to international marketing, i.e. the distribution of goods and services worldwide so that consumer goods eventually become universally accepted and homogeneous (Du Plessis \& Rousseau, 1999:132). Globalisation refers to the worldwide distribution of goods and services and is characterised by the expansion of worldwide economic relations and the extension of the Western capitalist economic system (Haake \& Jolivet, 2000). A global perspective on the other hand, entails the challenging of materialism and commercialism and an examination of one's role as citizen. It further includes global ethics. 
an attempt to promote sustainable consumption (Haake \& Jolivet, 2000, Shove \& Warde, 1998). The ideal is to convince people to become concerned with the impact of production and consumption behaviour on the environment, other cultures and even future generations (McGregor, 1998b). A global perspective is in essence a systems way of thinking (as opposed to a dualistic one) and focuses on problem solving and local as well as global implications of behaviour. It embraces a lifelong commitment, a willingness to support sustainable consumption, more responsible consumer behaviour and a focussed consumer socialisation process (McGregor, 1998a; McGregor, 1999c; Whitchurch \& Constantine, 1993:332). A system is defined as a collection of interrelated parts or subsystems that stand in relation among themselves and the environment and are unified by their design to obtain one or more objectives ${ }^{2}$ (Von Bertalanfy in Whitchurch \& Constantine, 1993:332; Spears \& Vaden, 1985:25). Within a systems approach the consumer as a primary unit is seen in interaction with his/her microenvironment (family) (Deacon \& Firebaugh, 1985:29), mesoenvironment (societal systems including socio-cultural, political and technological environments) and macroenvironment (international / global environment). The various parts of a system are organized in a hierarchical manner and boundaries between different hierarchical levels can either be closed or open (permeable) to allow influences from other environments into a specific subsystem. A global perspective inevitably necessitates an open systems approach characterised by equifinality, i.e. a willingness to follow alternative routes to obtain the desired outcome (Whitchurch \& Constantine, 1993:334). Insisting on consumer satisfaction per specified criteria (i.e. brand loyalty, store loyalty) reflects a closed systems approach because alternative choices are consciously ignored.

A global perspective results in an appreciation for voluntary simplicity and conservation, with a deeper respect for indigenous knowledge and how it is passed on to future generations. Ultimately, decisions are taken considering the effect on interactive environments rather than aiming to acquire and possess at all cost (Haake \& Jolivet, 2000; McGregor, 2000; McGregor, 1999a). A 'mind shift' from indiscriminate consumption to socially conscious and environmentally responsible consumption behaviour where the consumer is regarded as citizen, then becomes the norm (Follows \& Jobber, 2000; McGregor, 1999a; McGregor, 1998a; McGregor, 1998b). Somewhat in contrast to what students are often taught, consumer satisfaction would then result from 'other-directed' outcomes rather than a strict evaluation of product attributes. This requires a whole new approach to consumer education and consumer facilitation strategies so that a balanced appreciation of product attributes and the effect of the purchase on others and the different environments will determine decision-making.

2 Objectives are listed later in this article as the basic principles of a global perspective.

\section{ECONOMIC PRINCIPLES RECONSIDERED}

A global perspective necessitates a conscious reconsideration of fundamental economic principles in consumer decision-making behaviour (McGregor, 1998b). The following assumptions cover the scope of the challenge to be faced to achieve the desired outcome.

\section{The formal economy}

In the twenty-first century consumers are encouraged to spend their money well and to support retail to the benefit of the growth of the economy. Consumers have become accustomed to the dominance of retail giants that literally sell anything under the sun under one roof. Through monopolies, major retailers manage to provide a wide range of goods and services at very competitive prices. Concepts like 'chain store' and 'franchise' have become very popular and consumers can literally buy the exact product in almost the exact same store, almost anywhere in the country. Slogans like 'the consumer is king' and increased consumer support systems are furthermore used to gain consumer loyalty. In the end, retail giants make it almost impossible for enthusiastic entrepreneurs who start small businesses to survive.

A global perspective is in favour of small businesses and the informal sector for the sake of job creation and balance in the economy (McGregor, 1998b). Engberg (in McGregor, 1998b) uses the concept 'whole economy' to include small businesses and the informal sector in an interdependent system where the interactive roles of large as well as small businesses are acknowledged to obtain equilibrium. Equilibrium in this instance refers to a situation where the survival and growth of major businesses in combination with the informal sector contribute to household subsistence, continued production and community activity of especially underdeveloped communities (McGregor, 1998b).

In practical terms it would mean that a consumer's decision on where to buy has to be based on the effect of that decision on the wellbeing of others ${ }^{3}$ even if one has to compromise certain preference criteria and product outcomes. Consumer satisfaction then becomes more than the objective evaluation of product characteristics. In a systems approach, this reflects the principle of equifinality (Whitchurch \& Constantine, 1993:334): a consumer selects a product via another route, even if it means tolerating some inconvenience, paying more or waiting a bit longer.

\section{Consumer demand}

Economically speaking, consumer demand is determined by the amount of a product or service that a consumer is willing to buy at a certain price (McGregor, 1998b). Mayer (1991 in McGregor, 1998b) explains that consumers have a vote in the maintenance of market structure in the sense that

3 Others refer to other citizens, other cultures and even those not yet born (McGregor, 1998b) 
'every time a purchase is made, a ballot is cast'. Over-emphasis on price often leads to practices such as over active "bargaining" and often, the deliberate 'exploitation' of others. Within a global perspective this is unacceptable as the interactive contribution and wellbeing of all in terms of maintaining the rest of the system is recommended.

\section{Producer supply}

Advocating sustainable lifestyles, a global perspective places production and profits secondary to human, societal, environmental and global wellbeing and guards against any practices that may result in environmental degradation that strain local supply. For the same reason, technology that exceeds the level of the local culture is discouraged (McGregor, 1998b). This necessitates alternative choice criteria on the demand side and a commitment by suppliers in terms of corporate accountability and socially responsible behaviour.

According to Korten (1996) sustainable development centres on achieving the sustained economic growth needed to meet human needs, to improve living standards, and to provide the financial resources needed for environmental protection. Bubolz and Sontag (1993:425) accentuate the interdependence of the people of the world (the so-called human family) on the earth's resources and describe the world's 'ecological health' to be dependant upon decisions and actions taken by nations, as well as individuals and families. The collective wellbeing of individuals and families should therefore be considered part of the wellbeing of the whole ecosystem where decisions at microlevel eventually impact at the macrolevel in the broadest (global) sense because the interactive effect of subsystems (permeable boundaries) cannot be ignored. It has to be understood that everybody relies on the earth's resources and that 'overuse' of certain resources by more fortunate, developed groups is to the disadvantage of others and future generations.

Haake and Jolivet (2000:1) allege that globalisation is largely to be blamed for current environmental problems: (over) extraction of natural resources, massproduction of material goods and stress on the capacity of the natural environment through emissions and waste are mentioned as issues that need to be addressed. Ecological modernisation is suggested as a 'coping mechanism' to deal with substance-flow in modern society. Instead of a plea for the total dismantling of capitalism, ecological modernisation is based on sets of criteria developed during the 1980's and 1990 's that allow for decisions on ecological rationality of certain technologies, production arrangements and even complete sectors of industry (Spaargaren, 1999:2). Outcomes of such decisions have led to conscious attempts to promote recycling, to prevent pollution, to encourage the use of 'green products', energy awareness and an encouragement of the use of sustainable energy resources. The holistic view of the ecological theory of people in interaction with their environments (a global perspective) is ideally suited to address the inequalities caused by overconsumption. Humans have to accept a responsibility of stewardship with respect to other living organisms as well as to the non-living environment (conservation of the environment) to sustain future life (Bubolz \& Sontag, 1993:427, 433; McGregor, 1998a).

Sustainable development thus has two sides - sustainable production (supply) and sustainable consumption (demand). The supply-side focuses on the economic, social and environmental impact on production processes, while the demand-side focuses on the consumer's choice of goods and services to fulfil basic needs and to improve quality of life (McGregor, 2000). For sustainable development, those involved in production should realise that the earth's carrying capacity has to be respected (Jernolöv \& Jernolöv, 1993).

\section{Social costs of market transactions}

Consumers have buying patterns as well as discharge patterns and have proved to be major creators of waste (Haake \& Jolivet, 2000). The social costs involved (benefits enjoyed as opposed to negative effects) in producing and using products have thus become a major concern. A global perspective appreciates attempts to limit waste production, pollution and noise factors and accentuates that the social costs for others (other cultures, other countries, other communities) should be calculated and incorporated in every business policy and transaction so that the interactive effect of transactions are for the benefit of all (McGregor, 1998b).

In a systems approach, the so-called permeable boundaries reflect the situation: the effect of decisions of one community on another is deliberately accommodated. Every consumer therefore has a responsibility and a contribution to make towards sustainable consumption by adapting attitudes, preferences and decisions to prevent the undermining of others (including future generations) and/or damage to the environment.

\section{Marginal utility}

Diminishing marginal utility refers to the contradicting phenomenon that consumer satisfaction tends to decrease if the price of a product increases although the basic properties of the product remain unchanged. In contrast, a global perspective favours the principle of paying more for an item that includes some monetary contribution to the living condition of other communities (McGregor, 1998b). At the end of the day it becomes more and more difficult and confusing to formulate evaluation criteria for goods and services because a global perspective views objective evaluation criteria secondary to implicated advantages for others and the environment.

\section{Substitution effect}

Within the economics paradigm a consumer almost automatically opts for a substitute when the relative price of a product increases. A global perspective on 
the other hand, advocates that consumers should seriously reconsider purchases in terms of the global integrity of the close substitute. The merit of a purchase should therefore be questioned rather than automatically selecting a substitute (McGregor, 1998b).

\section{Scarcity and opportunity costs}

Time and money are considered decisive resources in an economics paradigm and when consumers' wants and needs exceed their level of resources, trade-offs are made to reach goals within financial and time limitations. The ethical and moral concerns of a global perspective direct the focus of a decision on human, social and environmental concerns rather than time and money (McGregor, 1998b).

\section{Inflation}

In a materialistic society, in terms of standard of living and spending power, inflation ${ }^{4}$ is a prominent issue (Gregory, 1990:399). Inflation is generally regarded as a threat to prosperity because it reduces discretionary income and increases cost of living. A global approach requires a re-evaluation of the effect of inflation in terms of who the beneficiaries from inflation are. It is suggested that if rising prices are caused by more money flowing to disadvantaged communities for produce and services rendered, inflation should be tolerated rather than be objected to in principle. The fact that higher incomes earned by disadvantaged communities might eventually contribute to peace, justice, security and freedom at home or elsewhere in the world should be regarded a priority. From a global perspective, the challenge is to accept the principle that consumers' rights are secondary to human rights (McGregor, 1998b).

\section{Present and future value}

A global perspective is opposed to extravagance and places a high premium on saving for the future and investing rather than borrowing (McGregor, 1998b). Within a systems way of thinking, it implies that saving will minimize the negative effect of inflation (that is suggested to be 'tolerated' for the sake of the implicated positive effects on the wellbeing of others).

\section{BASIC PRINCIPLES OF A GLOBAL PERSPECTIVE AND PRACTICAL IMPLICATIONS FOR CON- SUMER SCIENCE}

Although the underlying principles of a global perspective challenge modern consumers to make a mindshift and a lifelong commitment, the outcomes promise to be very rewarding. In the South African context, Afrocentricity that in essence opposes materialism (that is very typical of a Eurocentric approach and represents a value orientation where inclusive group participation

4 Inflation refers to the sustained increase in the general price level as a result of monetary causes and a simultaneous decline in the buying power of money (Gregory, 1990:399). exemplifies the collective African will (Du Plessis \& Rousseau, 1999:332), support certain principles of a global perspective. The concept Ubuntu that means that a person can only be a person through other people, illustrates the 'domino-effect' of consumers' behavioural patterns (interactive relationship and interdependency of parts of a system) suggested in a systems approach (Whitchurch \& Constantine, 1993:29).

The following principles capture the assumptions of a global perspective (McGregor, 1999c). Suggestions and examples are included to illustrate that any call for action upon consumers, citizens or professionals, should be very practical and acceptable to succeed and ultimately become a lifestyle.

\section{Perspective consciousness}

Because one's view of the world is not universally shared, no single perspective can be forced onto everybody. It becomes even more difficult when consumers' own money is involved, when personal use of commodities is criticized and when sacrifices have to be made for issues that individuals do not necessarily support. Petkus (1992) uses 'non animal tested cosmetics' as an example of products associated with 'environmental responsibility'. Unfortunately not all people share the same sentiments and it might take more than a simple argument to motivate consumers to refrain from using products tested on animals unless they can see 'what is in it for them'. Mobilizing consumers to become "other directed" rather than self directed (an abstract concept) and to publicly praise consumers' or a community's contribution to the well being of the earth and its resources through statistics, advertisements etcetera (a concrete measure) might be the only way to make consumers more aware of their role in the larger system, to convince them to make a contribution and to succeed. Consumers are often blamed while little or no attempt is made to inform and include them.

\section{State of the planet awareness}

The ideal is to develop an awareness of prevailing and emerging world conditions. Packaging can be used as an example: an awareness of the negative effect of certain packaging materials on the environment will facilitate the redesign and acceptability of alternatives in practice. Unfortunately packaging is generally considered an important attribute during product evaluation and the perception of product quality. Unless consumers are educated and motivated to reconsider, the existing problem of pollution will prevail (BechLarsen, 1995). Cooperation between retail and industry with the assistance of consumer advisors and media to introduce new methods and to simultaneously promote them as being more desirable would be the only way to bring about change.

\section{Cross-cultural awareness and diversity}

An appreciation of a diversity of ideas and practices in human societies and communities should be ac- 
knowledged and even encouraged. Walker (1992) blames the media for promoting a Eurocentric value system as the ultimate goal. Especially disadvantaged consumers and those in developing communities are easily encouraged to adopt Westernised lifestyles that - in the media - are presented as being socially desirable and a way of reflecting progress (Ger \& Belk, 1996). This has for example resulted in major changes in the eating habits of the black population of South Africa (from the traditional diets that are low in fat and sugar and high in fibre, to westernised diets that include high quantities of refined and processed foods) and has culminated in problems such as tooth decay, obesity, hypertension and cancer. Unless attention is given to diversity to the extent that advantages of certain cultural practices are publicly communicated and encouraged in schools, popular magazines and radio and television programmes, a westernised lifestyle as it is promoted and displayed in the media will remain a threat.

\section{Knowledge of global dynamics}

It is important to comprehend key traits and mechanisms of the world order to fully grasp consumer behaviour and the resulting consequences. Many of the 'newly rich' blacks in South Africa today value a luxury car as a status symbol (Du Plessis \& Rousseau, 1999:332) and many up-and-coming blacks prefer wearing imported clothing to reflect their success. Such practices lead to money flowing out of the country instead of the money being available to support local structures. Only through an appreciation of local goods and an understanding of how support of local structures can contribute to growth and prosperity within a community, can positive outcomes be expected. Consumers will have to be informed about the larger picture so that they understand how they will benefit in the long run. Efforts to inform consumers and incentives to encourage consumers to participate will have to come from influential role players: the business world, retail as well as consumer advisors who interact with consumers at various levels on a regular basis.

\section{Awareness of changing choices and alternatives}

Sensitivity towards problems faced by people within a larger global system is encouraged. Genetically engineered foods, plant biotechnology and genetically modified crops are examples of practices that are used to improve food quality, to enhance crops' resistance to pests and herbicides and to increase the levels of food production (Mackey \& Santerre, 2000). Modern technology can make a considerable contribution to maximising production but to enable consumers to make informed decisions on whether or not to use these products, consumers have to be informed of the consequences of such practices and risks that might be involved (such as cancer, exhaustion of land, etc.).

\section{A balance between demands and supply}

Strain on local supply needs to be addressed. Gussow (2000) explains that the underlying ecological imperative for eating locally, is to create real sustainability in terms of local and global food supplies. As an example he states that ".....it is energetically insane to chill perishable foods and transport it thousands of miles across oceans and national borders so we can have fresh peppers in Boston - in February". Many of the out-of-season foods on the tables of Americans are grown outside their borders by people whose health is threatened by malnutrition and who are paid minimal wages for their labour in the lands by companies who initiate such farming practices under the 'economic umbrella' of lowered production costs. An alternative would be to pay more for such foods to make the effort worth their while, and/or to encourage poor communities to produce for own consumption so that they at least are well fed and properly nourished.

\section{Voluntary simplicity}

It is recommended that people strive towards more modest lifestyles that require fewer possessions and lower consumption levels. Materialism has many advantages from an economics point of view, but an over-emphasis on possessions and status objects has resulted in many problems for consumers who, in an attempt to meet social requirements, have to deal with the negative impact of their lavish consuming practices. Mittner (2000) for example reports that money spent on cell phones and lottery tickets have resulted in lower expenditure on basic commodities such as food and clothing in households to the detriment of their standard of living (Ger \& Belk, 1996). Educating consumers to understand the long-term implications of extensive aspiration levels should thus be a high priority.

In the fashion industry, the Diderot effect that refers to the matching of clothing items that requires a constant and never-ending replacement of items is a practical example of the promotion of consumption levels. Specialisation has caused similar problems: consumers now buy running shoes, training shoes, squash shoes and tennis shoes - while previous generations used the same shoes for different activities. People also used to go rambling in old clothes. Today, specially designed clothing and equipment bearing the brandnames and designer labels are preferred (Shove \& Warde, 1998).

\section{Complementary technology}

Technology that is compatible with local, indigenous technology for the sake of preserving such practices for future generations has to be encouraged. Ger and Belk (1996) are of the opinion that globalisation results in certain goods being accepted as more desirable and unique and consumers bending over backwards to acquire specific objects. If globalisation's success is theoretically measured in terms of how successful goods and services are distributed world wide so that it becomes possible that 'we all have the same whereever we are' one could use the counter 
argument to promote South Africa's unique artefacts and cuisine as "something out of the ordinary". Being proud of what is South African should become prominent in our decision-making behaviour.

\section{International reciprocity}

What can be gained and contributed through crosscultural interaction and sharing should become a priority. Instead of exploiting poorer communities as cheap labour to reduce production costs, they can be uplifted by contracting them to produce certain commodities for more affluent communities. Instead of then paying minimal wages, prices of products should be increased to provide a higher income for the workers that could contribute to the prosperity of such communities. Logos such as 'made with dignity' could be used to encourage consumers to buy such products knowing that they are contributing to a worthy cause (Gussow, 2000).

\section{Sustainable lifestyles and production}

An attempt should be made to ensure that current collective lifestyles and production methods renew and support rather than harm the environment, ecosystems and are beneficial for future generations. Integrating sustainable development with a market- and growth-driven economy that is so skilfully promoted in media is difficult. Fortunately, according to Pantzar et al (1994) environmentalism has become an acceptable and fast growing trend in consumer behaviour and marketing. Consumer awareness of environmental issues and concern for the environment grew considerably during the late 1980's and in the 1990's.

Various obstacles have however prevented the transforming of positive attitudes into practical realities. Consumers have hardly any information of the effects of their choices on nature, other people, or future generations and environmental concerns often have to compete with individual utilitarian aspects. The willingness of the individual to make responsible choices often falters in the absence of powerful norms, and due to feelings of insignificance of one's own actions as well as a distrust of the 'responsible' behaviour of others (such as business and industry) (Pantzar et al, 1994; Follows \& Jobber, 2000; Testing time for greenness, 1997).

The textile industry has over the last two decades made a considerable contribution towards environmental conservation. Harmful effluent from textile mills and textile processing plants has been reduced and more environmentally friendly production and finishing processes have been introduced (Hatch, 1993:190191; Dickson, 2000; Rigby, 1993; Living within earth's limits: the quest for sustainable consumption, 1997). Biotechnology (where bacteria and enzymes are used to digest, transform and synthesise natural materials from one form to another) is encouraged to reduce strain on the environment. In an interesting development to protect consumers from counterfeit products, biocoding (through the use of monoclonal antibodies) is used as a marking system for instance on brandname denims. Anti-microbial textiles are newly developed textiles with bacteria-killing properties and are of great value for the medical profession due to their ability to contain the spread of infectious diseases and thus indirectly protect the environment (Byrne, 1995).

The development of biodegradable detergents is another positive development by industry to the advantage of the environment (Joseph, 1986:282). In Finland, for instance, the use of concentrated washing detergents has reduced the volumes of detergents used by households - a concept perfectly compatible with a global approach. The use of phosphate-free detergents has also reduced the load of phosphates in effluents caused by household washing detergents in the past few years while new materials used in household textiles require lower washing temperatures so that less energy is consumed (Groot-Marcus \& Van Moll, 1996). Consumer scientists have a responsibility to familiarize consumers with these alternatives while industry has to introduce and promote these practices.

\section{Systems consciousness}

Consumers should develop the ability to think in a systems mode so that the effect of one's actions on others and the environment eventually supersedes personal, self-centred motives. The only way to become a socially conscious consumer who supports sustainable living is by linking basic consumer rights with personal responsibility that obligate consumers to be accountable for their actions (Follows \& Jobber, 2000; McGregor, 1999a; McGregor, 1998b). Consumers often dispose of products before such are worn out. Household appliances are a perfect example of products that are often replaced while still in working order without thinking of the consequences in terms of the resources used to produce such appliances and the fact that the discarded metals are not always recycled for further use. Irresponsible behaviour of this type can be very disastrous for future generations (Cooper, 1994).

\section{Involvement consciousness}

Consumers will have to begin to understand the repercussions of their choices and actions in terms of the global present and future. What is needed is a growing awareness of the impact of personal and business decisions on personal and environmental health, to move away from the 'throw-away' mentality and to make a concerted effort to make things last longer. Also, to become accustomed to buying certain used and second-hand items - something that is simply not done in certain socio-economic groups. Consumers that value how they affect others and how others affect them, are more inclined to give serious consideration to substituting one product for another that might last longer or that might cause less damage to the environment (McGregor, 1998b). 
A diversity of ethical consumption experiences can also be given to illustrate the importance of understanding the repercussions of our behaviour and choices on others. For example, evaluating appliances in a major store that takes the trouble to display and install them and then buying what you need through an 'around the corner' shop with little infra structure at a lower cost, is unfair to the owner of the bigger store who walks the extra mile in an effort to satisfy consumer needs (Cooper-Martin \& Holbrook, 1993). Although it is recommendable that small business should be supported, it is unethical and unfair if their business is based on effort made by major stores and consumers should not encourage or support such practices.

\section{Process mindedness}

A commitment towards lifelong learning and socialization to continuously reconsider actions and behaviour in terms of the needs of the time, is the ultimate objective. Although many products are considered to be 'the socially acceptable choice', they are not always purchased. Consumers often try to compensate through exhibiting responsible post-purchase behaviour, for instance by buying products in non-returnable containers and then re-using them (Follows \& Jobber, 2000; Living within earth's limits: the quest for sustainable consumption, 1997). Consumers also seem to confuse conservation with sacrifice and austerity rather than viewing it as an important key to a satisfactory future standard of living (Testing time for greenness, 1997). Individual consumer actions, as well as the policies of business and government, will be significant in the transition from a world of seemingly unlimited abundance, to one where the efficient use of resources is practiced (Bannister \& Bonsma, 1980).

\section{Responsible value deliberations and morally justi- fiable decisions}

A willingness to compromise so that decisions are based on facts as well as values rather than habit has to be adopted. Mayer (2001:2) contends that advertising is a major factor in [American] society in creating and maintaining a peculiar form of narcissism ideally suited to consumerism. Advertising stimulates artificial needs within people that directly conflict with their capacity to form a satisfying and sustainable relationship with the natural world. If advertising could have the same impact on promoting environmentally responsible behaviour, the ideal of a satisfied, environmentally conscious consumer could be attained sooner. This may reduce their standard of living as defined purely by physical consumption, but also offers opportunities for an improved quality of personal, family and community life (McGregor, 1999b).

\section{CONCLUDING REMARKS}

Professionals in the discipline of consumer science have a major role to play in the process of convincing consumers to accept and adopt a global perspective in their day to day decision-making behaviour. Driven by materialistic lifestyles and being bombarded with the economic principles of buyer behaviour, consumers might find it difficult and might even resist making the mind shift. In an article on conservation published recently in National Geographic (Earth pulse: 2001), the alarming tempo of the affluent countries of the world's use of natural resources is reported and compared to that of third world countries. Using the term "footprint:" it is reported that at the moment, humankind is using one third more resources than nature could replenish. The USA for example, is currently using more than ten times the amount of resources per capita than is used per person in India. If one further takes into consideration that the world population is increasing by 77 million each year, we are heading for a disaster! Unless we commit ourselves to take action, to review our behaviour and to motivate others to do the same, the highlights of today might turn out to be the nightmares of the future.

\section{LIST OF REFERENCES}

BANNISTER, R \& BONSMA, C. 1980. Classification of concepts in consumer education. [WWW document- 10/04/2001] URL http://www.emich.edu/public/coe/nice/classi.html BECH-LARSEN, T. 1995. Consumer attitude to food packaging - with a focus on purchase decisions. Journal of Consumer Policy 18:340-344.

BUBOLZ, MM \& SONTAG, MS. 1993. Human ecology theory, in Boss, PG, Doherty, WJ, Larossa, R, Schum, WR \& Steinmetz, SK (eds). Sourcebook of family theories and methods. A contextual approach. New York. Plenum.

BYRNE, C. 1995. Biotechnology in textiles. Textile Institute's Dyeing and Finishing Group Conference. Nottingham. [WWW document - 02/11/1997]. URL http://www. davidrigbyassociates.com/articles/htm

COOPER, T. 1994. Beyond recycling. The longer life option. The New Economics Foundation (November): 2-22.

COOPER-MARTIN, E \& HOLBROOK, MB. 1993. Ethical consumption experiences and ethical space. Advances in Consumer Research XX:113-118. [sl]. Twenty third annual conference. Association for Consumer Research.

DEACON, RE \& FIREBAUGH, FM. 1985. Family resource management. Principles and applications. 2nd ed. London. Allyn \& Bacon.

DICKSON, PR. 2000. Understanding the trade winds: the global evolution of production, consumption, and the Internet. Journal of Consumer Research 27 (June):115-123.

DU PLESSIS, PJ \& ROUSSEAU, GG (1999): Buyer behaviour. A multi cultural approach. 2nd ed. Johannesburg. Thomson.

FOLLOWS, SB \& JOBBER, D. 2000. Environmentally responsible purchase behaviour: a test of a consumer model. European Journal of Marketing 34(5/6):723-746.

EARTH PULSE (2001): We leave more than footprints. National Geographic. July.

GER, G \& BELK, RW. 1996. Consumptionscapes of the less affluent world. Journal of Consumer Policies 19: 271304.

GREGORY, PR. 1990. Essentials of economics. 2nd ed. London. Scott Foresmann.

GROOT-MARCUS, AP \& VAN MOLL, M. 1996. Textile characteristics, laundering and the environment.

Journal of Consumer Studies and Home Economics 20 (3):261-273.

GUSSOW, JD. 2000. Ecological perspective: Is local vs 
global the next environmental imperative? Nutrition Today 35 (4):120-128.

HAAKE, J \& JOLIVET, P. 2000. Towards sustainable consumption: an analytical framework for a globalised world. (Draft paper). [WWW document - 25/04/2001]. URL http:// www.cybercable.tm.fr/

HATCH, KL. 1993. Textile science. New York. West.

JERNOLÖV, A \& JERNOLÖV, S. 1993. Sustainable development and sustainable consumption.

[WWW document - 29/04/2001]. URL http://www.iisd.ca/ linkages/consume/inst-sd.html

JOSEPH, ML. 1986. Introductory textile science. $5^{\text {th }}$ ed. New York. Holt, Rinehart and Winston.

KORTEN, D. 1996. Sustainable development: conventional versus emergent alternative wisdom. [WWW document 10/04/2001]. URL http://dieoff.com/page86.htm

LIVING WITHIN EARTH'S LIMITS: THE QUEST FOR SUSTAINABLE CONSUMPTION. World consumer rights day 1997. [WWW document - 29/04/2001]. URL http://193.128.6.150/consumers/rightsday97/chapter1/living. $\mathrm{html}$

MACKEY, MA \& SANTERRE. 2000. Biotechnology and our food supply. Nutrition Today 35(1):120-128.

MAYER, D. 2001. Institutionalising over consumption. [WWW document - 05/03/2001]. URL http://www.bilderberg. org/ncl.htm

McGregor, SLT. 1998a. Reinterpreting economic theory in a global reality. Journal of Family and Consumer Sciences 90 (3):35 - 40

McGregor, SLT. 1998b. Towards adopting a global perspective in the field of consumer studies.

Journal of Consumer Studies and Home Economics 22 (2):111-119.

McGregor, SLT. 1999a. Globalizing consumer education: Shifting from individual consumer rights to collective human responsibilities. Proceedings of the $19^{\text {th }}$ International Consumer Studies and Home Economics Research Conference (September): 43-52.

McGregor, SLT. 1999b. Socializing consumers in a global marketplace. Journal of Consumer Studies and Home Economics 23(1):37-45.

McGregor, SLT. 1999c. Towards a global mind set for family/ consumer economics and resource management educators. Proceedings of the Western Region Home Management
Family Economic Educators Conference (October):2-7. McGregor, SLT. 2000. The family perspective in sustainable consumption and development.

[WWW document - 11/04/2001]. URL http://www. consultMcGregor.com

MITTNER, M (2000): SA selfoon- en dobbelnasie van formaat. Beeld:18 Augustus.

PANTZAR, M, RAIJAS, A \& EEISKANAN, E. 1994. Green consumers? Greening consumption?

[WWW document- 29/04/2001]. URL http://www.iisd.ca/ linkages/consume/inst-pan.html

PETKUS, E. jr. 1992. Implications of the symbolic interactionist perspective for the study of environmentally responsible consumption. Advances in Consumer Research IXX 861-868. Twenty second annual conference. [sl]. Association for Consumer Research.

RIGBY, D. 1993. Textiles for the $21^{\text {st }}$ century: new products and processes with a wider potential. [WWW document 27/11/1997]. URL http://www.davidrigbyassociates.com/ articles/davos.htm

SCHIFFMAN, LG \& KANUK, LL. 2000. Consumer behavior. London. Prentice Hall.

SHOVE, E \& WARDE, A. 1998. Inconspicuous consumption: the sociology of consumption and the environment (draft). Centre for Science and Department of Sociology. Lancaster University. http://www.comp.lancaster.ac.uk/sociology/ socaw001.html

SPAARGAREN, G. 1999. The ecological modernisation of domestic consumption. Consumption, everyday life \& sustainability. Summer School 1999. [WWW document 29/04/2001].

URL http://www.comp.lancs.ac.uk/sociology/esf/spaargaren. htm

SPEARS, MC \& VADEN, AG. 1985. Food service organizations. New York. Mc Millan.

TESTING TIME FOR GREENNESS. World consumer rights day 1997. [WWW document - 29/04/2001]. URL http://193.128.6.150/consumers/rightsday97/chapter2/ testing.html

WALKER, ARP. 1992. Trends of nutritional intake patterns of South African interethnic populations. Continuous Medical Education 10(8)1395-1399.

WHITCHURCH,GG \& CONSTANTINE, LL. 1993. Sourcebook of family theories and methods. New York. Plenum. 